\title{
The World Bank on Mind, Behaviour and Society
}

\section{Elise Klein}
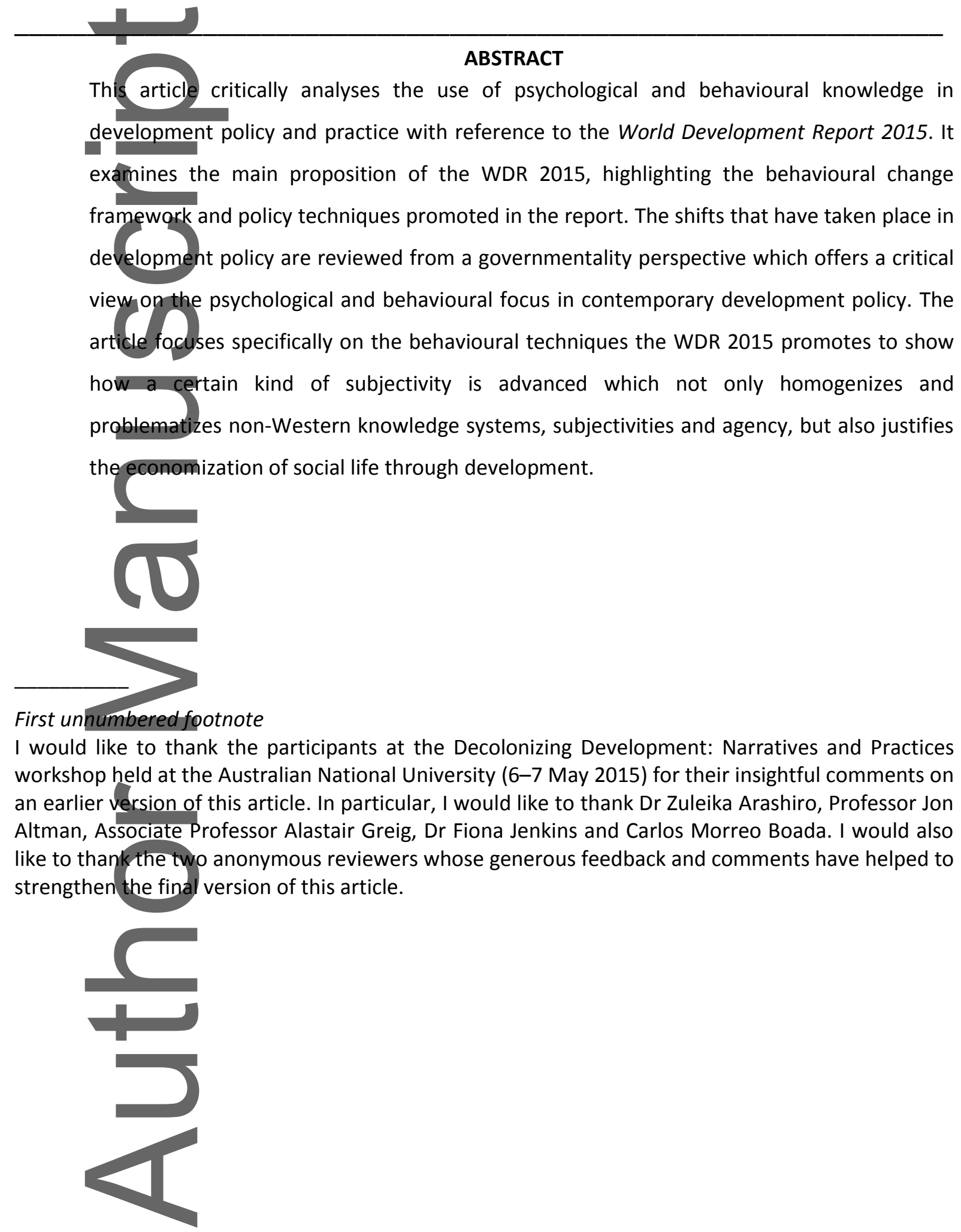

This is the author manuscript accepted for publication and has undergone full peer review but has not been through the copyediting, typesetting, pagination and proofreading process, which may lead to differences between this version and the Version of Record. Please cite this article as doi: $\underline{10.1111 / \text { dech. } 12308 .}$.

This article is protected by copyright. All rights reserved. 


\section{INTRODUCTION}

Each year, the World Bank publishes a World Development Report (WDR). The objective of these reports is to direct development discourse and set the policy agenda on pressing global development issues (Berger and Beeson, 2010). In 2014, the World Bank released its World Development Report 2015: Mind, Society and Behavior which explicitly focuses on the psychological domain. The World Development Report 2015 (WDR) aims to:

integrate recent findings on the psychological and social underpinnings of behavion to make them available for more systematic use by both researchers and practitioners in development communities. ... these findings help explain decisions that individuals make in many aspects of development, including savings, investments, energy consumption, health and child rearing. ... this approach expands the set of tools and strategies for promoting development and combating poverty. (WDR, 2014: 2-3).

The general focus of the WDR is on the decision-making ability and behaviour of individuals to enable them to make better choices in regard to economic development. Authored by economists and behavioural economists from inside the Bank, and advised by scholars in economics and sociology, the report advances specific interventions that target the psychological domain.

The WDR 2015 has attracted attention from development scholars such as Fine et al. (2016), who analysed the World Bank's use of behavioural economics in the WDR 2015. This current article extends the work of Fine et al. (2016) by arguing that the WDR 2015 should be read as part of a larger neoliberal shift in development policy and practice (Ferguson, 2015; Standing, 2014). Of particular note is how social and political complexity and contestation in relation to development have been depoliticized through the economization of social life (Madra and Adaman, 2013; McMahon, 2015). In their article, Fine et al. (2016: 659) make a similar observation, stating that context, or what I refer to as social and political complexity, only emerges in the WDR 2015 to 'the extent that it allows a better understanding of the choice architecture facing individuals, rather than drawing attention to systemic or structural issues bearing on why poverty is reproduced'. The stakes are high as the focus on individual behaviour and a reduction in the analysis of structural issues actively diverts attention away from addressing these very structures.

This article critically examines the WDR's endorsement of the use of psychological knowledge and expertise against the backdrop of the behavioural shift which has taken place within development policy more broadly. First, I examine the main proposition advanced in the WDR 2015, highlighting the behavioural change framework and policy techniques the report promotes. Second, I review the shifts in development policy from a governmentality perspective, and critically examine the psychological and behavioural focus in development policy. Third, I analyse the behavioural

This article is protected by copyright. All rights reserved. 
techniques the WDR 2015 promotes and show how they reinforce a certain kind of subjectivity. I conclude by arguing that the advancement of these techniques not only homogenizes and problematizes non-Western knowledge systems, subjectivities and agency - it also justifies the economization of social life through development.

\section{THE 2015. WORLD DEVELOPMENT REPORT}

The WDR 2015 focuses on improving the efficiency and effectiveness of the decision making of recipients of development interventions. The general focus of the report is the behaviour and ability of subjects to make choices that would advance personal and global economic development. The authors identify three principles for understanding human behaviour which are to serve as framework in the design and implementation of development policy. The three principles outlined are (i) thinking automatically and habitual decision making; (ii) thinking socially and the impact of social norms and social recognition on decision making; and (iii) mental models, defined as culture, worldviews and ideology. Each principle is explained below.

First, the report claims that most judgements and choices people make occur automatically, not deliberatively. The authors call this 'thinking automatically' (WDR, 2014: 5), and then proceed to outline three elements that affect automatic thinking of the individual decision maker; how choices are framed to the decision maker, the environment and emotional situation of the decision maker, and the decision maker's bias from past experiences. The report then explicitly names ways in which automatic decision making can be thwarted, such as through 'choice architecture' (WDR, 2014: 6), a technique which allows professionals to organize the context in which decisions are made, so as to nudge people towards a particular choice.

Second, the authors argue that the way in which people think and act is often determined by what others around them think and do. They call this 'thinking socially' (WDR, 2014: 6). Specifically, they claim that [s]ocial networks can both aid and undermine the achievement of development goals. ... In other words, interventions achieve their objectives by harnessing some social pressures and diminishing others' (WDR, 2014: 50). Policy makers could therefore use social recognition and the power of social incentives to change decision-making behaviour, which could include rewarding, coercing, judging, embarrassing or reprimanding subjects.

Third, the authors argue that in any given society, individuals share a common perspective in order to make sense of the world around them and to understand themselves. This is called 'thinking with mental models' (WDR, 2014: 11). Mental models are defined throughout the report as worldviews, ideology and culture. It is interesting that, whilst the report examines the culture of the 'other', the mental model of the authors of the report is never scrutinized. That is, there is no critical

This article is protected by copyright. All rights reserved. 
reflection on the liberal norms or modernist orientation that inform the authors' approach, a point I will return to later.

The three principles are then applied to show how policy makers can improve development through manipulating or intervening at the level of habitual agency, social norms or mental models. This framework is deployed in the domains of poverty reduction, child development, household finance, productivity and reducing energy consumption. In this report, development is reduced to economic development; the behavioural attributes that are promoted have a human capital ${ }^{1}$ orientation, and the architects of development policy impose their normative view of development, regardless of alternative views.

In addition, the report presents techniques, examples and tools that policy makers can use on the subjects of their interventions. These psychological and behavioural techniques are intended to alter habitual decision making, social norms and mental models deemed ill-suited to economic development. What follows are five techniques presented and promoted in the WDR 2015.

Marketing existing social norms to shift behaviour. The report suggests using marketing technologies to help emphasize and effectively sell particular decisions to the citizenry. Using the example of tax compliance, the report argues that when people feel a tax system is fair and they see others are obeying the rules, they are more likely to pay their taxes. Therefore, the report suggests that marketing social norms that 'emphasize the extent of tax compliance and encourage the perception that tax evaders are deviants may be successful' (WDR, 2014: 52).

Using entertainment and film. The report discusses the example of a study that attempted to address what the researchers identified as the 'fatalistic aspirations' of people in Ethiopia. In this study Ethiopians with low aspirations were offered the opportunity to watch films featuring inspiring fellow Ethiopians. The documentaries illustrated how, 'by setting goals, making careful choices, persevering, and working hard' (WDR, 2014: 63), people could improve their socio-economic position. The reported outcomes of the study were threefold: first, the socio-economic aspirations of the subjects of the study were raised; second, the subjects increased their personal savings; and third, the subjects invested more resources in their children's schooling.

Using choice architecture and nudges. These are a set of technologies to encourage individuals to unconsciously favour certain options over others. Choice architecture is defined as influencing 'decision making by simplifying the presentation of options, by automatically evoking particular associations, or by making one option more salient or easier to choose than the

\footnotetext{
${ }^{1}$ The human capital approach promotes individual capabilities to the extent that capitalist development is advanced. It has been criticized by capability scholars because development is not synonymous with economic development and so other capabilities may be important (Sen, 1999).
}

This article is protected by copyright. All rights reserved. 
alternatives' (Thaler and Sunstein, 2008 cited in WDR, 2014: 36). Nudges go further, in that they achieve 'behavior change without actually changing the set of choices. It does not forbid, penalize, or reward any particular choices. Instead, it points people toward a particular choice by changing the default option, the description, the anchor, or the reference point' (WDR, 2014: 36). The report cites the example of sending text messages to people in Peru, Bolivia and the Philippines to remind them to save, which led to an increase in their savings.

Using conditions on cash transfers. This refers to the use of conditions on state-assisted payments implies, that recipients only receive such payments if they comply with certain conditions. For example, making state assistance for poor families conditional on their children attending school or getting vaccinated.

Using social pressure and praise to influence individual behaviour. This refers to the use of technologies that aim to influence the behaviour of individuals through the use of social network or group pressure and praise. The focus is on exerting social pressure, such as shame when people fail to repay loans or giving praise to encourage mothers to breastfeed their babies. This technique is thought to either alter undesirable or strengthen desirable individual behaviour.

\section{DISCURSIVE INTERVENTIONS AND GOVERNMENTALITY}

Development studies scholars have generated an extensive literature on how development interventions (policies, projects or programmes) are sites of contestation, perpetuating gendered, class and colonial structures (Cooke, 2003; Crewe and Harrison, 1998; Escobar, 1995; Ferguson, 1994; Li, 2007; Mohanty, 1988, 2003). Through development interventions, relations of power and knowledge intersect with the lived realities of those being developed (Chambers, 1997; Mosse, 2004). A development intervention therefore is never neutral. Rather, it is a tool that privileges particular meanings over others, which reproduces embedded systems of power, and directly affects the lived reality and well-being of 'recipients of development assistance'. Anthropologists of development have long held this view. Olivier de Sardan (2005), for example, argues that development policies and programmes support some groups' meanings and logics while simultaneously reducing space for the expression of the logics and meanings of other groups. In the case of development policy, 'progress', 'development', 'well-being' are all contested terms especially since they are generally defined through a Western lens and support the logic of Western modernity. As Western definitions of such terms are hegemonic in development policy, counter notions of development, such as those contesting liberalism and capitalism, can endure alterity. Whether disciplining or supporting in intent, the process of development policy and related interventions involve control over the interpretation of events and providing opportunities for some aspirations, while obstructing others (Mosse, 2004).

This article is protected by copyright. All rights reserved. 
Liberalism is a major knowledge system promoted through development discourse. ${ }^{2}$ It is a normative political doctrine that views individual liberty as an ends in itself. At a very fundamental level, liberalism involves not only a commitment to protecting individual liberty and private property but also a political project of individual self-regulation and responsibility (Hindess, 2001; Li 2007). This latter point is particularly illuminating, in that it highlights that liberalism concerns not only the defence of liberty but also the governance of liberty. Foucault (1994: 73-74), for example, views liberalism, hot as a theory, or an ideology and even less, certainly, as a way for "society" to represent itself ... but, rather, as a practice, which is to say, as a "way of doing things" orientated toward objectives and regulating itself by means of a sustained reflection'.

Liberal governmentality entails the use of soft power to govern citizens. It seldom involves coercion of populations; instead it focuses on enhancing the individual's capacity for self-regulation in line with a specific notion of the good (Li, 2007). The strength of soft power lies in the art of encouraging of the 'right' choices whilst maintaining the idea of the 'free self'. Drawing on Foucault, Tania Li (2007:5) suggests we understand liberal governmentality as:

The 'conduct of conduct', government is the attempt to shape human conduct by calculated means ... the concern of government is the well-being of the populations at large ... it is not possible to coerce every individual and regulate their actions in minute detail. Rather, government operates by educating desires and configuring habits, aspirations and beliefs. It sets conditions, 'artificially so arranging things so that people, following only their own self-interest, will do as they ought' (emphasis in the original).

Whilst liberal governmentality was a regime of power Foucault studied in Western societies, scholars have pointed out its relevance also to the (Western) project of development. Sanyal (2007), for example, traces the shifts in development policy since the early 1970s, when then World Bank President Robert McNamara expanded the Banks's narrow focus on economic growth and trickledown economics to include a combination of growth and poverty reduction. Following McNamara's lead, policy makers shifted their focus from how broad socio-economic and structural transformations could promote growth to how underdevelopment could be explained in terms of individual and market/government imperfections (Akbulut et al., 2015). Poverty reduction in essence became a project of managing populations (not structures), using 'evidence' to improve education, health and household deprivation. Whereas previously development was concerned with moving

\footnotetext{
${ }^{2}$ Liberalism underpins significant aspects of 'development', from the promotion of human rights (Anghie, 2004; Brown, 2000; Douzinas, 2000), and good governance (Nanda, 2006; Williams and Young, 1994), to health care (Henderson and Petersen, 2002) and individual responsibility (Burchell et al., 1991; Hamann, 2009).
}

This article is protected by copyright. All rights reserved. 
people from the traditional to the modern through economic accumulation, the shift to poverty reduction in conjunction with economic accumulation has turned the 'poor' into a quantifiable group that can be targeted for 'improvement'. This management of populations through measures, goals and targets is indeed a form a governmentality (Sanyal, 2007). Sanyal (2007) argues that, 'governmentality dispenses with the necessity of theoretically defining the poor; it constitutes him as an empirical category on which the techniques of governance can be applied' (Sanyal 2007: 179). Whereas policy focusing on poverty reduction promoted the improvement of specific variables such as education, health and mortality, the significance of the WDR 2015 lies in its inclusion of psychological, behavioural and cognitive attributes to be managed and regulated. It is the inclusion of these behavioural and psychological attributes that needs to be critically reviewed.

\section{LIBERAL GOVERNMENTALITY AND PSYCHOLOGICAL KNOWLEDGE AND EXPERTISE}

Historically, psychological knowledge and expertise emerged in the context of a liberal governmentality as a means to organize, govern and regulate populations in Western societies (Christopher and Hickinbottom, 2008; Danziger, 2006). The use of psychological knowledge is therefore 'intrinsically linked' (Rose, 1992: 351) with liberal governmentality. ${ }^{3}$ More specifically, the use of psychological knowledge can be traced to the mid- $19^{\text {th }}$ century. This was a time when governments of Europe and North America, still reeling from the expectations of Enlightenment revolutions of individual rights, had to ensure that citizens experienced the free will and choice promised by the liberal democratic project, but that they simultaneously acted as they should: in a responsible and accountable manner (Hook, 2004). The psychological conditioning and maintenance of the minds of citizens became an important technology to promote and sustain liberal societies. Subjectivity thus became 'a vital resource in the managing of the affairs of the nation' (Rose, 1999: $5)$.

Furthermore, the individual needed to be the basic unit of liberal societies in order to regulate and calculate progress. It was precisely through psychological expertise that the governance of individual citizens was made possible. In this regard, Rose (1999: 8) argues: 'Psychological inscriptions of individuality enable the government to operate upon subjectivity. The psychological assessment is not merely a moment in an epistemological project, an episode in the history of knowledge: in rendering subjectivity calculable it makes persons amenable to having things done to them - and doing things to themselves - in the name of their subjective capacities'.

In appearing technical and scientific, psychological expertise is assumed to be ethical and rational. Yet it is precisely through its ability to augment feelings of free will that psychological

\footnotetext{
${ }^{3}$ This historical shift is well documented by Foucault (1994) in what he calls 'bio-power'.
}

This article is protected by copyright. All rights reserved. 
expertise becomes an important tool for liberal governmentality. Liberal subjects seldom feel controlled or regulated in liberal democracies, rather they are encouraged to be autonomous, selfdefining and masters of their own destinies. Psychological expertise helps normalize these feelings and experiences through providing a benchmark of 'normal' agency, cognition and behaviour in relation to which we can seek to improve ourselves (Rose, 1992).

Western psychology can present itself uncritically, as detached from the wider processes of power and politics (Foster, 2004; Foucault, 1994; Hook, 2004, 2005; Klein, 2017; Mills, 2014). However, this discipline coupled with a development intervention - another apparatus of power presenting itself as neutral or even a force for 'good' - can make for a dangerous duo. Moreover, the neoliberal shift in governmentality has changed the way in which subjectivities are normalized, shaped and gutided by development policy. This shift has been facilitated by the use of psychological and behavioural expertise in development interventions. Of particular note is how individual efficiency, self-regulation and architectures of 'free' choice are developed to produce what is known as neoliberal subjectivities.

\section{Neoliberal Governmentality}

Neoliberalism, which has emerged in recent decades, has reconfigured the exercise of political power to resemble the logic of the market (Madra and Adaman, 2013; McMahon, 2015). Scholars understand and use the term neoliberalism in various ways (Ferguson, 2010). In their account, Madra and Adaman (2013) document the rise of three distinct schools of neoliberal rationalities. Whilst neoliberalism is often equated with laissez faire and the obsoleteness of the state, Madra and Adaman (2013) add nuance through an analysis of the Chicago, Austrian and post-Walrasian approaches.to neoliberal rationalities. More specifically, they show how these neoliberal rationalities can include not only a pro-market discourse but also a post-market discourse. A post-market discourse claims that, more often than not, markets are not enough in and of themselves and there is always room to design and implement 'incentive-compatible' mechanisms to efficiently reconcile the 'interests' of interacting actors. Whilst pro-market approaches tend to resist all corrective interventions and redistributionary efforts of the state, arguing that these would distort the economic signals that coordinate the activities of individuals, households and firms, post-market approaches call for such interventions and efforts, as long as they are 'economically sound' (Madra and Adaman, 2013: 692).

The pro-market Chicago approach to neoliberalism is suspicious of the state's ability to regulate the market. According to scholars of this approach the free market is an evolutionary force, where individuals are encouraged to fulfil their potential as entrepreneurs, through market mechanisms. Consequently, market deregulation is actively pursued in the Chicago approach, and government failures are viewed as the consequence of a lack of free markets (Madra and Adaman,

This article is protected by copyright. All rights reserved. 
2013). Whilst the Chicago school views the market as a means through which individuals can be regulated to enhance efficiency in a process akin to natural selection, the Austrian school views the individual as rational and a source of innovation and discovery which could feed cultural evolution and marketinnovation. The Austrian school is also highly suspicious of the state and regards it as ineffectual due to its rent-seeking and corrupt behaviour. In contrast to these two approaches, the post-market, post-Walrasian approach to neoliberalism does see a role for the state. In the Walrasian neoliberal approach, the state is a 'nexus of principal-agent relations' (Madra and Adaman, 2013: 702), and tasked with putting measures in place that protect individuals against moral hazards. Whilst state intervention may seem to be the antithesis to neoliberal approaches, according to Madra and Adaman (2013), the post-Walrasian approach remains a neoliberal approach because state intervention is employed to advance economic efficiency in line with what is thought best for the individual. Although the three approaches are distinct, what they do have in common is the economization of social and political life, along with the reduction of humans to homo economicus

Economization assumes that the market is the site of social and political truths and that the world can be understood through 'what the market tells us' (McMahon, 2015). The economization of social and politicallife has implications for the individual who is literally required to be their own business (Gershon, 2011). The individual is thus reduced to the rational, self-sufficient, economic actor affectionately called homo economicus (McMahon, 2015). As such, the self is 'produced through an engagement with a market', that is, neoliberal markets require participants to be reflective managers of their abilities and alliances' (Gershon, 2011: 539). Individual subjects are expected to operate in accordance with a market logic where responsible behaviour requires not only selfregulation but also economic effectiveness and efficiency (Barry et al., 1996; Burchell et al., 1991; Hamann, 2009). In this way, neoliberal governmentality transforms the manner in which individuals relate to themselves, each other and their environment, 'thereby potentially generating a change in the social being' (Madra and Adaman, 2013: 696).

This strong focus on the individual can depoliticize other social processes such as class, gender and colonization, and lead to the belief that poverty is the fault of individuals, for not being effective and efficient in their choices. The remedy from a neoliberal viewpoint is to adjust the behaviour and decision-making attributes of the individual, specifically in relation to their ability to be self-sufficient and responsible for themselves, their families and their communities (Gershon, 2011). The state can then fulfil the function of disciplining any individuals or groups who are unable to act as self-sufficient or effective agents.

This article is protected by copyright. All rights reserved. 
Whilst the belief exists that the role of the state is limited, neoliberal governmentality actually entails mass regulation (Cahill, 2014; Harvey, 2005; Standing, 2011). This is particularly important as the construction of the subject as homo economicus does not occur of its own accord, requiring some effort by the state and other actors to 'actively propound opportunism at the subjective level' (Madra and Adaman 2013: 696). Neo-paternalism characterizes these behavioural interventions, which is discussed in the next section.

\section{Psychology, Behavioural Economics and Development Interventions}

There is a tendency in neoliberalism to see poverty as a problem of the individual and thus related to economically inefficient and ineffective individuals (Saint-Paul, 2011). Consequently, development interventions have become more focused on improving individual behaviour and agency. Both psychology and behavioural economics have been instrumental in this policy shift.

Psychology has developed into many disciplinary strands and is not a single canon of knowledge. However, in the neoliberal era, Western psychological thought has been readily integrated into behavioural economics (Akbulut et al., 2015; Mills, 2014; WDR, 2014). This is partly because psychology's "capacity to lend itself "freely" to others who will "borrow" it because of what it offers to them in the way of a justification and guide to action' (Rose, 1999: 92).

Behavioural economics, which draws heavily on psychological expertise, plays an important role in neoliberal interventions as it provides a science for producing responsible, efficient and effective subjects. Regarded by some as revolutionary, behavioural economics fundamentally challenges the neoclassical notion of individual behaviour as the outcome of the thought processes of a rational, self-interested, utility maximizing, coherent and stable subject. Drawing on a vast body of psychological research, behavioural economics argues that individuals display non-standard preferences, beliefs and behaviours (Colin and George, 2004; DellaVigna, 2009; Kahneman, 2003). For example, DellaVigna (2009) argues that, contrary to the neo-classical economic argument which holds that preferences and decision making are temporally and spatially consistent, preferences can vary and change depending on individual beliefs and the time and context/environment in which they are situated. More recently, the field of behavioural economics has burgeoned due to an increased focus of neoliberal governments on predicting and shaping behaviour in the development process. McMahon (2015) argues that through its use of a market logic to explain human behaviour (rational and the irrational), behavioural economics actively reduces human behaviour to the logic of the market. Although behavioural economics challenges the veracity of the perfectly rational, selfinterested, utility-maximizing model of homo economicus, 'it does nothing to upset the broader model of an individual allocating scarce means to varied ends' (ibid.: 149). Due to the exclusion of

This article is protected by copyright. All rights reserved. 
psychopolitics from behavioural economics, this deepening of the understanding of the 'economic actor' actually furthers neoliberal governmentality.

Moreover and aligning with neoliberal governmentality, a key characteristic of behavioural economics is that the implementation of its principles does not require direct and continual application. That is, behavioural economic principles can be applied to govern individuals indirectly. Thaler and Suntein (2009), who are regarded as the fathers of behavioural economics, have developed an argument for integrating neo-paternalism ${ }^{4}$ with neoliberal ideas of non-state intervention.They insist that their 'libertarian paternalism' is not an oxymoron:

Libertarian paternalists urge that people should be 'free to choose'. We strive to design policies that maintain or increase freedom of choice. When we use the word libertarian to modify the word paternalism, we simply mean libertypreserving ... Libertarian paternalists want to make it easy for people to go their own way; they do not want to burden those who want to exercise their freedom. The paternalistic aspect lies in the claim that it is legitimate for choice architects to try to influence people's behaviour in order to make their lives longer, healthier, and better.. we argue for self-conscious efforts by institutions in the private sector and also by government, to steer people's choices in directions that will improve their lives'. (Thaler and Sunstein, 2009: 5-6 cited in Bielefeld, 2014: 293, emphasis in the original)

The 'nudge' is a mechanism of libertarian paternalism by means of which governments and development actors refrain from imposing particular decisions, while making some options more attractive and easier to choose than others. Sunstein (2013: 9) explains how 'nudges' function in the context of libertarian paternalism:

Nudges consist of approaches that do not force anyone to do anything and that maintain freedom of choice, but that have the potential to make people healthier, wealthier and happier. ... Those who favour nudges recognize the importance of freedom of choice. They respect free markets and private liberty. They allow people to go their own way. At the same time, they emphasize that people may err and that ... most of us could use a little help.

It is claimed that nudges encourage people to make decisions they actually want to make. However, policy makers make assumptions (as to what these might be) on the basis of certain

\footnotetext{
${ }^{4}$ A helpful distinction between 'old' paternalism and 'new' or neo-paternalism can be found in Dee (2013). Neo-paternalism refers to the commitment to realize behavioural change by means of conditions placed on state assistance and support. 'Old' paternalism does not necessarily have an explicit focus on behavioural change.
}

This article is protected by copyright. All rights reserved. 
normative ideas of development and progress on the basis of which they define and present the available options. In this regard, economic development and the economization of social life are held to be the hormative ideal of modern development (Sen, 1999). The use of this mechanism is therefore highly controversial given that being nudged a particular direction may not be the preference of the individual were they to be made aware, not only of the politics of the policy decision, but also broader political and economic processes that are contributing to their poverty or economic insecurity. Neo-paternal interventions control choices and decisions in favour of the market and economic development whilst excluding alternative aspirations (McMahon, 2015; SaintPaul, 2011). Furthermore, the nudge is highly interventionist, made all the more questionable by the fact that the individual may not even be aware that he or she is being subjected to it. As such, neopaternalism and its related technologies have become an important mechanism by means of which populations are governed.

Whereas others have provided illuminating and helpful critiques of these neo-paternalistic approaches (see Altman, 2007; Bielefeld, 2014; Coons and Weber, 2013; McMahon, 2015), the focus of this article is the endorsement of the WDR 2015 of behavioural economics and psychological expertise as technologies to influence the norms and agency of subjects to achieve economic development. The report states, 'Engineering shifts in social norms is a far from a trivial task. Yet norms can and do change' (WDR, 2014: 53). The WDR 2015 promotes liberal paternalism as an approach to poverty reduction. These technologies give the appearance of reinforcing freedom and autonomy while the choices offered are augmented and regulated in a manner that is consistent with a neoliberal logic.

The behavioural techniques promoted in the WDR 2015 include marketing certain social norms over others; the use of nudges; using film and entertainment to encourage the pursuit of certain social aspirations; and using social pressure and placing conditions on support to effect particular behaviour. These techniques are the result of the economization of social and political life through a strong focus on individual economic efficiency and effectiveness. As such they are highly contentious

To illuminate this point, it is useful to revisit the film example outlined earlier involving a study of Ethiopians with low aspirations watching films featuring inspiring Ethiopians as a way to raise low socio-economic aspirations. Examining the film intervention shows not only a drastic narrowing of the focus on the individual, which risks over-simplification of the problem, it also suggests that through positive thinking and role modelling, material realities will change. Agency undoubtedly is an important element of social change, however, encouraging the notion of free will and stimulating higher expectations are problematic if oppressive structures are not identified and

This article is protected by copyright. All rights reserved. 
addressed. Moreover, positive thinking and higher aspirations are not sufficient to reduce poverty and inequality, and can actively divert attention from the structural dimension underlying poverty and hardship (Klein, 2014; Standing, 2014).

Similarly, and adding to the previous discussion, using nudges and choice architecture to encourage more desirable social outcomes has been criticized as redefining a socio-economic crisis to a problem of (in)efficiency and (in)effectiveness of the individual (Standing, 2014). This is particularly the case when poverty and underdevelopment are individualized while ignoring the increasingly precarious labour market and income insecurity faced by many, both the global South and the global North. Likewise, employing social pressure and praise to influence individual norms and behaviours can also depoliticize social complexity. It is not clear which group in a social network will be targeted or how the empowering or disempowering would take place. Indeed, these measures enact a highly political process that engages relations of power to create winners or losers. As the report renders the government, market and associated actors neutral, it is not clear by whom and to what end these technologies may be used legitimately. Consequently, this technique is presented as apolitical and economically viable whilst obscuring the underlying social and political complexities, which consequently remain unaddressed.

Regarding the use of conditional cash transfers for behavioural change, it is useful to consider the kinds of conditions and the kinds of behaviours the conditional cash transfer technology is trying to produce. The report is complimentary of the Colombian government, which, in order to increase school attendance, imposed the condition of school attendance on families in exchange for state payments. However, other governments have used similar programmes aimed at behavioural change that have been problematic. For example, the Australian government, through its School Enrolment and Attendance Measure (SEAM) programme, suspends entire state payments to Indigenous families if parents are unable to ensure that their children comply with the government's enrolment and attendance policy. Indigenous education policy in Australia is regarded by some scholars as a form of neo-colonialism and the behavioural focus of the programme overlooks the educational needs of Indigenous students (Bielefeld, 2013; Billings, 2009).

\section{BEHAVIOURAL ECONOMICS AND SHIFTING DEVELOPMENT POLICY}

The WDR 2015 has embarked on the ambitious task of developing policy that encourages recipients of development interventions to make better choices. The mechanisms of governmentality it endorses purportedly enhances self-regulation, especially with respect to choices and decisions people make in the economic domain. In addition to the concerns expressed above about the techniques promoted, the report further depoliticizes social and political complexity in two ways. First, it does so through the extreme individualization and problematization of the individual.

This article is protected by copyright. All rights reserved. 
Second, although the development industry is presented as neutral and apolitical, the report consistently treats development as economic development.

\section{Problematizing-Individual Agency}

From the outset, the report assumes a deficiency in the agency of the recipient of development interventions. This is done through identifying individual decision making as the starting point, then proceeding to explain how individual decision making and behaviour can be manipulated in order to enhance individual efficiency and effectiveness in realizing economic development goals.

In the chapter on improving household finance, the authors outline deficiency in individual behaviour and decision making arguing that, 'the empirical evidence suggests that behavior and decisions driven by impatience, procrastination and temptation are economically relevant' (WDR, 2014: 114) Furthermore, the report concludes by stating that lack of self-control is a leading explanation for lack of savings, and the absence of default savings plans for most people in developing countries makes the problem worse' (WDR, 2014: 120). In both instances, the inference is made that the economic situation of an individual can be attributed to behavioural factors. The statements also suggest that through some simple behavioural modifications, economic situations can improve. Problematizing individual agency locates the site of poverty reduction in the individual, which overlooks the socio-economic and historical factors that generate and reinforce poverty and inequality As such, the report risks being a manual that presents coping strategies rather than engaging with the complexities involved in addressing poverty and inequality.

The example is given of Novi, a mother from urban Jakarta who decides to invest in the stock market. The report states: 'Although her gains outweigh her losses, she feels much more concerned about the losses, and after some time she withdraws most of the funds from the stock market. She keeps a few stocks that have fallen significantly in value, hoping to sell them when prices recover' (WDR, 2014:113). According to the authors, Novi's behaviour is economically sub-optimal, and they proceed to suggest ways in which policy makers can modify her behaviour. The authors suggest mechanisms to encourage Novi to take decisions that are economically driven, such as refraining from withdrawing funds from the stock market. These suggestions are made without acknowledging Novi's agency; that.perhaps she is well aware of the volatility of financial markets, and is withholding investment to protect her family. Another aspect that is not considered is why the emphasis is on Novi building individual financial investment capability and not on collective capabilities or structures that would provide a more secure economic environment.

Beyond the example of Novi, the problematization of agency in the report excludes analysis and discussion of agency as resistance to and subversion of economic development policies. Acknowledgement of resistance is important and there are individuals and groups that actively resist

This article is protected by copyright. All rights reserved. 
neoliberal governmentality. For example, some policy commentators have characterized Indigenous peoples in Australia who refuse to participate in the Australian government's welfare-to-work programmes as behaviourally deficient and 'lazy'. However, research has shown the limitations of the behavioural deficiency critique. Indeed, by not turning up for these programmes, many Indigenous peoples are in fact actively resisting assimilation into a neoliberal and neo-colonial Australia (Jordan, 2016). The analysis and discussion of effective choices and decision making purely with a view to realizing economic ends not only overlooks agency as resistance as a field of enquiry, it actively silences it.

\section{Neutrality of the Development Industry}

The focus of the WDR 2015 is on the effectiveness and efficiency of individual subjects of development. Development as a process, and the industry supporting it, however, is never questioned. A simitar observation was made by Tania $L i$ in relation to development interventions in Indonesia: ‘They [development officials and policy makers] pay very little attention to the power relations implicit in their own self-positioning. The will to empower others hinges upon positioning oneself as an expert with the power to diagnose and correct a deficit of power in someone else' (Li, 2007: 275) In the WDR 2015, the project of development - its goals, the normative ideas upheld, or the power relations implicit in development - is not scrutinized. The strong focus on development as economic development is a particular source of concern.

Economic development is a contested concept and not necessarily a quick remedy to reduce poverty. In many cases, economic development has had a negative effect on various marginalized communities (Ferguson, 1994; Godoy et al., 2005). Indeed, persistent poverty is relational, a 'consequence of historically developed economic and political relations', rather than 'residual', an understanding 'which might regard poverty as the result of being marginal to these same relations' (Bernstein, 1992 cited in Mosse, 2010: 1157). Post-development scholars not only reject the project of development but also denounce the overarching grand narratives of Western modernity that ground much of development discourse (Escobar, 1995; Ferguson, 1994; Latour, 1993; Mignolo, 2011). Such scholars concentrate specifically on the 'cultural and discursive logics of development as a specific form of Western imperialism and ideological domination' (Robins, 2003: 269). Postdevelopment theorists aim to transform the structures and processes that are oppressing societies and peoples, opting for plural, locally-controlled hybrid economic systems and forms of governance.

Instead of examining the suitability of promoting behavioural and psychological technologies for economic development, the authors of the WDR 2015 subscribe to a particular neutrality. This neutrality is called normative neoliberalism (Hay, 2007), where the mode of governance is one of economization and depoliticization, not only of the individual but the whole of social and political

This article is protected by copyright. All rights reserved. 
life. The report presents the neutrality of the development industry first with reference to a moral responsibility to intervene, and second with reference to targeting the mental models of individual policy makers

For example, on the last two pages of the report, the authors make the argument as to why development policy actors should engage in shaping the behaviours and decision-making abilities of people subjected to development interventions. Drawing on an example from John Stewart Mill's (1859/2005) On Liberty, concerning a man about to cross a dangerous bridge, the WDR states:

[I]t is a proper office of public authority to guard against accidents. If either a public office or anyone else saw a person attempting to cross a bridge which has been ascertained to be unsafe, and there were no time to warn him of his danger, they might seize him and turn him back, without any real infringement of his liberty; for liberty consists in doing what one desires, and he does not desire to fall into the river. (WDR, 2014: 202)

The authors continue, 'Just as that man did not desire to fall into the river, most of us do not want to be forgetful, to procrastinate, or to miss out on important opportunities' (WDR, 2015: 202). Unfortunately though, the WDR 2015 does not question the promotion of neoliberal economic development as 'the good'. This is problematic because consistent with the view that poverty is an individual problem, governments are to intervene in a manner that is for the poor's own good.

Insofar that conflicting ideas or notions of the good are acknowledged in the report, the authors invoke 'human rights' as 'guiding principles for addressing trade-offs' (WDR, 2014: 202). However, this is to overlook the paradoxical nature of human rights which is well documented in the critical literature. These scholars argue that the idea of human rights is deeply rooted in Western liberalism and cannot be treated as or assumed to be a universal notion of the good (Anghie, 2004; Brown, 2000, Douzinas, 2000). Due to its inability to address the structures and processes of global capitalism promoting inequality, underdevelopment and economic insecurity, the human rights regime has also been criticized for acting as cover for neoliberalism (Douzinas, 2000; Kang, 2009; Kirkup and Evans, 2009).

The impossibility of neutrality is acknowledged in the report only with reference to the bias of the individual development professional. The most critical passage in the report reads as follows: 'Development initiatives and discourse are replete with phrases espousing the virtues of "participation," "empowerment" and "accountability," for example. But as articulated by development practitioners, these concepts largely reflect the sensibilities of donor agencies and urban elites' (WDR, 2014: 186-7). The report nevertheless stops short of problematizing the idea of development which is regrettable. It would have offered an opportunity to reflect on the problematic nature of the idea of development as economic growth, the potential neo-colonial

This article is protected by copyright. All rights reserved. 
nature of interventions, and the moral questions that arise from using of psychological expertise to manipulate agency. Instead, the report yet again reduces the analysis to the level of the individual. The development policy maker becomes the site of interrogation, rather than the discursive environment in which they are produced and act. The report specifically emphasizes the need for development professionals to become more aware of their bias and the tendency to look for answers that fit their preconceived ideas. Drawing on research from the private sector, the reports suggests following a strategy of immersion to bridge the gap between the reality of development professionals and that of the poor. Accordingly, the report advises 'development professionals to "eat their own dog food": that is, they should try to experience firsthand the programs and projects they design' (WDR, 2014: 190). Yet the report does not analyse the quality of the ingredients of the 'dog food' prescribed - economic development and the application of behavioural and psychological technologies to render the subject of development more governable.

The report is thus marked by an underlying psychopolitics whereby subjectivities are manipulated to suit and reproduce a neoliberal framework. The report's focus on influencing individual choices and decision making to realize a notion of the good that is uncritically embraced is such that the structural exploitation and oppression inherent in the development project it advances is completely disregarded. The risk this brings is that the approach outlined becomes a strategy, not for improving people's lives, but for maintaining the status quo of neoliberal economic development

Although strong reservations are expressed in this article regarding the promotion and use of psychological and behavioural expertise in development policy and interventions, it does not necessarily mean that there is no place for the psychological domain in the formulation of development policy. This would, however, require extensive empirical research that seeks to understand and itluminate the social and political complexities surrounding global development.

In this regard, it may also be worth exploring Paolo Freire's (1970) notion of conscientization, a process which aims to help people understand and contest systemic structures of oppression. Conscientization broadly involves three steps: first, people are engaged in dialogue about theiroppression; second, people come to understand the mechanisms of dehumanization and oppression; and third, people use their new critical knowledge to actively contest oppression (Carr, 2003). Freire's pedagogy for the oppressed was not merely a 'different take on reality' through positive thinking, leaving the objective situation intact. Instead, 'concientización [conscientization] supposes that persons change in the processes of changing their relations with the surrounding environment and, above all, with other people' (Martín-Baró 1994: 41). Conscientization uses selfdefined psychological processes to engage with oppression, which helps people to contest this

This article is protected by copyright. All rights reserved. 
oppression and reclaim power. In his pedagogical development of conscientization, Freire characterized conscientization as anti-paternalistic; there is no predetermined destination or individual/leader who knows where the process would go. Instead, people would, in the process of conscientization and through the exploration of processes of power and structures of domination, find their own waywith it. Whilst this critical consciousness approach provides a possible entry point for thinking about development policy, the limits of the development industry to harness its radical potential may be its undoing. That this can easily happen is illustrated by Batiwala (2007) who documents the watering down of the Freirean approaches the development industry in India.

\section{CONCLUSION}

This article has critically examined the central proposition of the WDR 2015: Mind, Behavior and Society. The WDR proposes to incorporate psychological and behavioural techniques into development interventions so as to help individual recipients make more effective and efficient decisions. Through tracing the development of psychological and behavioural expertise as a technology of neoliberal governmentality, the article identified and discussed some of the tensions, assumptions and discontinuities in the report.

It was argued that the report reduces subjectivity to a mere means to serve the pursuit of economic development. This is achieved through the promotion of specific behavioural and psychological techniques which disregard social and political complexity. Of particular concern is how the authors, through focusing on individual behaviour, overlook the consequences of structural exploitation and oppression inherent in economic development. This is a policy trend scholars must continue to criticize and contest.

It was also argued that there is a need to reintroduce social and political complexity in development policy. One method that should be taken seriously is the development of critical consciousness which enables people to define their own notion of development and contest and oppose oppressive systems and structures. This may well challenge the very premise of the development industry, but perhaps this is precisely what is required in the present neoliberal era.

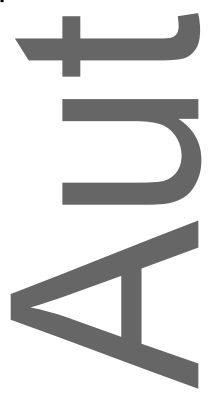

This article is protected by copyright. All rights reserved. 


\section{REFERENCES}

Akbulut, B., F. Adaman and Y. Madra (2015) 'The Decimation and Displacement of Development Economics', Development and Change 46(4): 733-61.

Altman, J. (2007) 'The Howard Government's Northern Territory Intervention: Are Neo-Paternalism and Indigenous Development Compatible?'. Topical Issue 16/2007. Canberra: Center for Aboriginal Economic Policy Research.

Anghie, A. (2004) Imperialism, Sovereignty and the Making of International Law. Cambridge: Cambridge University Press.

Barry, A., T. Osborne and N. Rose (1996) Foucault and Political Reason: Liberalism, Neo-liberalsm and Rationalities of Government. Chicago, IL: University of Chicago Press.

Batiwala, S. (2007) 'Taking the Power out of Empowerment - Experiential Account', Development in Practice 17(4): 557-65.

Berger, M. and M.Beeson (2010) 'Lineages of Liberalism and Miracles of Modernisation: The World Bank, the East Asian Trajectory and the International Development Debate', Third World Quarterly 19(3): 487-504.

Bernstein, H. (1992) 'Poverty and the Poor', in Henry Bernstein and H. Johnson (eds), Rural Livelihoods. Crises and Responses, pp. 13-26. Oxford: Oxford University Press.

Bielefeld, S. (2013) 'Conditoinal Income Support Under SEAM: Human Rights Compatability Issues', Indigenous Law Bulletin 8(9): 17-21.

Bielefeld, S. (2014) 'Income Management and Indigenous peoples: Nudged into a Stronger Future?’, Griffith Law Review 23(2): 285-317.

Billings, P. (2009) 'School Enrolment and Attendance Measures: More Trials for Aboriginal Families?', Indigenous Law Bulletin 3(5): 1-4.

Brown, W. (2000) Suffering Rights as Paradoxes', Constellations 7(2): 230-41.

Burchell, G, C. Gordon and P. Miller (1991) The Foucault Effect: Studies in Governmentality. Chicago, IL: University of Chicago Press.

Cahill, D. (2014) The End of Laissez-Faire?: On the Durability of Embedded Neoliberalism. Cheltenham: Edward Elgar Publishing.

Carr, E.S. (2003) 'Rethinking Empowerment Theory Using a Feminist Lens: The Importance of Process', Affilia 18(1): 8-20.

Chambers, R. (1997) Whose Reality Counts? Putting the First Last: London, ITDG Publishing.

Christopher, J. and S. Hickinbottom (2008) 'Positive Psychology, Ethnocentrism, and the Disguised Ideology of Individualism', Theory and Psychology 18: 563-89.

Colin, C. and L. George (2004) Behavioral Economics: Past, Present, Future. Princeton, NJ: Princeton University Press.

This article is protected by copyright. All rights reserved. 
Collins, A. (2004) 'Theoretical Resources', in D. Hook (ed.) Critical Psychology, pp. 1-23. Cape Town: University of Cape Town Press.

Cooke, B. (2003) 'A New Continuity with Colonial Administration: Participation in Development Management', Third World Quarterly 24(1): 47-61.

Coons, C. and M Weber (2013) Paternalism: Theory and Practice. Cambridge: Cambridge University Press.

Crewe, E. and E. Harrison (1998) Whose Development. An Ethnography of Aid. London: Zed Books.

Danziger, K. (2006) 'Universalism and Indigenization in the History of Modern Psychology', in A. Brock (ed) Internationalizing the History of Psychology pp. 208-25). New York: New York University Press.

Dee, M. (2013) Welfare Surveillance, Income Managment and New Paternalism in Australia', Surveillance and Society 11(3): 272-86.

DellaVigna, S. (2009) 'Psychology and Economics: Evidence from the Field'. Journal of Economic Literature 47(2): 315-72.

Douzinas, C. (2000) The End of Human Rights: Critical Legal Thought at the Turn of Century. Oxford: Hart Publishing.

Escobar, A. (1995) Encoutering Development: The Making and the Unmaking of the Third World.

Princeton, NJ: Princeton University Press.

Ferguson, J. (1994) The Anti-Politics Machine: Development, Depoliticisation, and Bureaucratic Power in Lesotho, Cambridge: Cambridge University Press.

Ferguson, J. (2010) 'The Uses of Neoliberalism', Antipode 41: 166-84.

Ferguson, f. (2015) Give a Man a Fish: Reflections on the New Politics of Distribution. Durham and London: Duke University Press.

Fine, B., D. Johnston, A. Santos and E. van Waeyenberge (2016) 'Nudging or Fudging: The World

Foster, D. (2004) 'Liberation Psychology', in D. Hook (ed.) Critical Psychology, pp. 559-602.

Development Report 2015', Development and Change 47(4): 640-63.

Cape Town: University of Cape Town Press.

Foucault, M. (1994)' 'The Birth of Biopolitics', in P. Rabinow (ed.) Michel Foucault Ethics:

Subjectivity and Truth (Vol. 1), pp. 73-80. London: Penguin Books.

Freire, P. (1970) Pedagogy of the Oppressed. London: Penguin Books.

Gao, Z. (2012) 'The Emergence of Modern Psychology in China, 1876-1922', Annual Review of Critical Psychology 10: 1-15.

Gershon, I. (2011) 'Neoliberal Agency', Current Anthropology 52(4): 537-55. 
Godoy, R. et al. (2005) 'The Effect of Market Economies on the Well-being of Indigenous Peoples and on their Use of Renewable Natural Resources'. Annual Review of Anthopology 34: 121-38.

Hamann, T. (2009) 'Neoliberalism, Governmentality, and Ethics', Foucault Studies 6: 37-59.

Harvey, D. (2005) A Brief History of Neoliberalism. Oxford: Oxford University Press.

Hay, C. (2007) 'Genealogies of Neoliberalism', in R. Roy, A. Denzau and T. Willett (eds) Neoliberalism: National and Regional Experiments with Global Ideas, pp. 51-70, Abington: Routledge.

Henderson, S. and A. Petersen (2002) Consuming Health. New York: Routledge.

Hindess, B. (2001) 'The Liberal Government of Unfreedom', Alternatives: Global, Local, Political 26(2): 93-111.

Hook, D. (2004) Critical Psychology. Cape Town: University of Cape Town Press.

Hook, D. (2005) 'A Critical Psychology of the Postcolonial'. Theory Psychology, 15(4), 475-503.

Igarashi, Y. (2006) 'Role of Critical Psychology in Japan: Protest Against Positivistic Psychology and Search for new Knowledge of the Mind'. Annual Review of Critical Psychology 5: 156-66.

Jackson, M. (1990) 'The Man Who could Turn into An Elephant: Shape-shifting Among the Kuranko of Sierra Leone', in J. Micheal and K. Ivan (eds) Personhood and Agency: The Experience of Self and Other in African Cultures, pp. 59-78. Acta Univesitatis Upsaliensis, Uppsala: Almqvist \&Wiksell International Publishing.

Jordan, K. (2016) Better than Welfare? Work and Livelihood for Indigenous Australians after CDEP. Canberra: ANU Press.

Kahneman, D. (2003) 'Maps of Bounded Rationality: Psychology for Behavioral Economics', American Economic Review 93(5): 1449-75.

Kang, S. (2009) 'The Unsettled Relationship of Economic and Social Rights and the West: A Response to Whelan and Donnelly', Human Rights Quarterly 31(4): 1006-29.

Karp, I. (1988) 'Laughter at Marriage: Subversion in Performance', Journal of the Folklore Institute 25(1-2): 35-52.

Kirkup, A. and T. Evans (2009) 'The Myth of Western Opposition to Economic, Social and Cultural Rights? A Reply to Whelan and Donnelly', Human Rights Quarterly 31(1): 221-37.

Klein, E. (2014) 'Psychological Agency: Evidence from the Urban Fringe of Bamako', World Development 64(C): 642-53.

Klein, E. (2017) Developing Minds: Psychology, Neoliberalism and Power. Oxford: Routledge.

Latour, B. (1993) We have Never been Modern. Cambridge, MA: Harvard University Press.

Li, T. (2007) The Will To Improve: Governmentality, Development and the Practice of Politics. Durham, NC: Duke University Press. 
Madra, Y. and F. Adaman (2013) 'Neoliberal Reason and its Forms: De-politicisation through Economisation', Antipode: A Radical Journal of Geography 46(3): 691-716.

Mansfield, N. (2000) Subjectivity: Theories of the self from Freud to Haraway: New York University Press.

Martín-Baró, I. (1994) Writings for a Liberation Psychology. Cambridge, MA: Harvard University Press.

McMahon, (2015) 'Behavioural economics as neoliberalism: Producing and governing homo economicus', Contemporary Political Theory 14(2): 137-58.

Mignolo, WD. (2011) The Darker Side of Western Modernity: Global Futures, Decolonial Options. Durham, NC: Duke University Press.

Mill, J.S. (1859/2015) On Liberty, Utilitarianism and Other Essays. Oxford: Oxford University Press.

Mills, C. (2014) Decolonizing Global Mental Health: The psychiatrization of the majority world. New York: Routledge.

Mohanty, C.T. (2003) “'Under Western Eyes” Revisited: Feminist Solidarity through Anticapitalist Struggles', Signs 28(2): 499-535.

Mohanty, C.T. (1988) 'Under Western Eyes: Feminist Scholarship and Colonial Discourses', Feminist Review $61-88$.

Mosse, D. (2004) 'Ts Good Policy Unimplementable? Reflections on the "Ethnography of Aid Policy and Practice"', Development and Change, 35(4): 639-71.

Mosse, D. (2010) 'A Relational Approach to Durable Poverty, Inequality and Power', The Journal of Development Studies 46(7): 1156-78.

Nanda, V.P. (2006) 'The "Good Governance" Concept Revisited', Annals of the American Academy of Political and Social Science 603: 269-83.

Olivier-de-Sardan, J-P. (2005) Anthropology and Development: Understanding Contemporary Social Change. Lohdon : Zed Books.

Riesman, P. (1990) 'The Formation of Personality in Fulani Ethnopsychology', in J. Micheal and K. Ivan (eds) Personhood and Agency: The Experience of Self and Other in African Cultures, pp. 169-90. Acta Univesitatis Upsaliensis, Uppsala: Almqvist \& Wiksell International Publishing

Robins, S. (2003) Whose Modernity? Indigenous Modernities and the Land Claims after Apartheid', Development and Change 34(2): 265-86.

Rose, N. (1992) 'Engineering the Human Soul: Analyzing Psychological Expertise', Science in Context $5(2): 351-69$.

Rose, N. (1999) Governing the Soul: The Shaping of the Private Self. London: Free Association Books. 
Saint-Paul, G. (2011) The Tyranny of Utility: Behavioural Social Science and the Rise of Paternalism. Princeton, NJ: Princeton University Press.

Sanyal, K. (2007) Rethinking Capitalist Development: Primitive Accumulation, Governmentality and Post-colonial Capitalism. Oxford: Routledge.

Sen, A. (1999) Development asFfreedom. Oxford: Oxford University Press.

Standing „ G. (2011)The Precariat: The New Dangerous Class. London: Bloomsbury.

Standing, G. (2014)A Precariat Charter: From Denizens to Citizens. London: Bloomsbury Academic.

Sunstein, C. (2013) Simplier: The Future of Government. New York: Simon and Schuster.

Teo, T. (2015) Critical Psychology: A Geography of Intellectual Engagement and resistance', American Psychologist 70(3): 243-54.

Thaler, R. and C.ISunstein (2009) Nudge: Improving Decisions About Health, Wealth and Happiness. London: Penguin Books.

Viveiros de Castro, E. (2013) 'Native as Relationality', HAU: Journal of Ethnographic Theory 3(3): 46971

WDR (2014) World Development Report 2015: Mind, Society, and Behavior. Washington, DC: World Bank.

Williams, D. and T. Young (1994) 'Governance, the World Bank and Liberal Theory', Political Studies 42(1): 84-100.

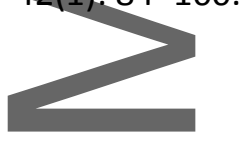

Elise Klein (elise.ktein@unimelb.edu.au) is a Lecturer of Development Studies, School of Social and Political Scjences, University of Melbourne, Australia. Her research interests include the psychologization of development interventions, women's agency, neoliberal subjectivities, economic rights and Indigenous development. Her new book is Developing Minds: Neoliberalism, Psychology and Power (Routledge, 2016).

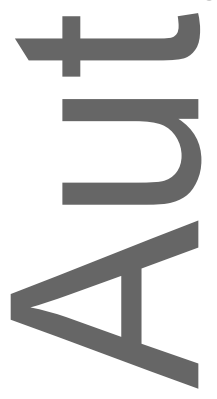

This article is protected by copyright. All rights reserved. 


\section{University Library}

\section{- M M I E R R V A gateway to Melbourne's research publications}

Minerva Access is the Institutional Repository of The University of Melbourne

Author/s:

Klein, $\mathrm{E}$

Title:

The World Bank on Mind, Behaviour and Society

Date:

2017-05-01

Citation:

Klein, E. (2017). The World Bank on Mind, Behaviour and Society. DEVELOPMENT AND CHANGE, 48 (3), pp.481-501. https://doi.org/10.1111/dech.12308.

Persistent Link:

http://hdl.handle.net/11343/292827

License:

Publisher's own licence 